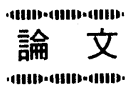

\title{
炭素材料の機械的性質のかたさ試験による評価
}

\author{
奥 達雄*, 太田進哉**, 衙藤基邦*** \\ 黒田浩二****, 田那村武司*****
}

(平成4年7月17日受理)

\section{An Evaluation of Mechanical Properties of Carbon Materials by Hardness Test}

\author{
Tatsuo Oku*, Shinya Ohta**, Motokuni Eto***, \\ Koji Kuroda**** and Takeshi Tanamura***** \\ *Department of Mechanical Engineering, Faculty of Engineering, \\ Ibaraki University, Hitachi 316, Japan \\ **Graduate Student, Department of Mechanical Engineering, \\ Faculty of Engineering, Ibaraki University, Hitachi 316, Japan \\ ***Japan Atomic Energy Research Institute, \\ Tokai-mura, Ibaraki 319-11, Japan \\ ****Toyo Tanso Ltd., Oosaka 555, Japan \\ $* * * * *$ Shikibo Ltd., Shiga 527, Japan
}

A dynamic ultra-microhardness test, bending tests and Young's modulus measurements were performed on three grades of $\mathrm{C} / \mathrm{C}$ composite and twelve grades of nuclear graphite. In hardness tests the indented load(L) versus depth(h) curves were obtained on loading and unloading processes. The parameters $B$ and $D$ were obtained by using $L / h$ versus $h$ relationships on loading and unloding processes, respectively. The correlations of the mean value of $\mathbf{B}$ with the bending strength and of the mean value of D with the Young's modulus were examined. As a result, no clear proportional correlations were found between the B and D values and the bending strength and Young's modulus of all of the tested carbon materials, respectively. However, correlations were found between bending strength and mean value of $\mathrm{B}$ on most of the graphite materials and between Young's modulus and mean value of $\mathrm{D}$ on fiber axis direction of a $\mathrm{C} / \mathrm{C}$ composite. With the correlations the strength and Young's modulus of fine structures of the $\mathrm{C} / \mathrm{C}$ composite have been attempted to evaluate.

Keywords: $C / C$ composite, graphite, load-depth relation, bending strength, Young's modulus

\footnotetext{
* 茨城大学工学部： 个316 日立市中成沢町 4-12-1

** 茨城大学大学院工学研究科 (同上)

*** 日本原子力研究所： $=319-11$ 茨城県那珂郡東海 村
}

東洋炭素株式会社：干555 大阪市西淀川区竹島 ***** 敷島紡績株式会社：干527 滋賀県八日市市紫原 南町 


\section{1. 緒言}

黑鉛材料は，高温ガス炬においては，減速材，反射材 として多量に使用される。燃料体に用いられる黑鉛も減 速材として使用されており，炬心部はほとんど炭素構造 物で構成されているといってよい。最近，JT-60などの 核融合装置のプラズマ対向壁材として, 黒鉛材料はもち ろん炭素複合材料のうち特にC/Cコンポジットが有望視 され，多く利用されている。プラズマ対向壁材料に要求 される特性は, 優れた熱的・機械的性質及びトリチウム 吸収特性等である。とりわけ，プラズマ対向壁面に垂直 な方向の熱伝導率は良好なことが望ましい。C/Cコンポ ジットでは, バルク材の熱的・機械的性質は炭素繊維及 びマトリックス材の特性によって支配される。バルクの 状態で各微細組織の特性を評価し, バルク材の特性と比 較検討することが可能であれば，バルク材としての優れ た特性をもつ材料を開発するのに役立つ知見を得ること ができると考えられる。1 $\mathrm{gf}$ 程度の荷重を用いる超微小 かたさ試験は, 金属材料については, 適用が成功裹に進 められているといってよい)。しかし，炭素材料につい ては適用する試みが最近行われたばかりである2)。その 結果, 上記のような微細組織の機械的性質の評価が可能 となることが示唆されている゙๋。

本研究では, まず, 多くの原子炉級炭素材料に対して ダイナミック超微小かたさ試験を適用した結果得られた 知見を用いて， 1 種類の C/Cコンポジトについて超微小 かたさ試験を行い, 各微細組織の機械的性質を評価し, それらと繊維自身及びバルクの特性との比較検討を試み た。

\section{2. 実験方法}

供試材料として, Table 1に示すように, C/Cコンポ ジット 3 種類, 原子炉用黒鉛を含む炭素材料 12 種類を用 いた。3D-C/Cは敷島紡績 (株) 製, CC-312 は昭和電工 (株) 製，CX-2002U と IG-110U，IG-15，IG-43，IG-56, ISEM-3, ISO-88, SIC-6は東洋炭素(株)製，HCB-18Sは日 立化成(株)製，7477はLe Carbone Lorraine社(仏)製， IM-2はAnglo Great Lakes Carbon Corp.(英)製，H-327は Great Lakes Carbon Corp.(米)製, ETP-10はイビデン(株) 製である。3D-C/Cは，3次元の瀻維配向をなす C/Cコン ポジット, CC-312とCX-2002Uはともにフェルト系C/C コンポジットでともに超高純度処理材(灰分10ppm以下) であり, 繊維の直径は顕微鏡観察から数 $\mu \mathrm{m}$ から $10 \mu \mathrm{m}$ 程度であることを確認した。IG-11は石油コークス系微 粒( 20 20m)等方性黒鉛で, その高純度処理材IG-110は日 本原子力研究所で建設中の高温ガス炉(高温工学試験研
Table 1 Apparent density, Young's modulus and bending strength of carbon materials tested.

\begin{tabular}{lccc}
\hline $\begin{array}{l}\text { Properties } \\
\text { Materials }\end{array}$ & $\begin{array}{c}\text { App. Density } \\
\mathrm{kg} / \mathrm{m}^{3}\end{array}$ & $\begin{array}{c}\text { Young's Modulus } \\
\text { GPa }\end{array}$ & $\begin{array}{c}\text { Bending Strength } \\
\text { MPa }\end{array}$ \\
\hline 3D-C/C & 1770 & $120 /-$ & $102 /-$ \\
CC-312 & 1805 & $40.3 / 5.1$ & $78 / 19$ \\
CX-2002U & 1650 & $10.0 /-$ & $44 /-$ \\
\hline HBC-18S & 1980 & 5.4 & 88.2 \\
7447 & 1760 & $9.5 / 10.0$ & $34.1 / 33.1$ \\
IM-2 & 1780 & $12 / 11.9$ & $33.6 / 34.4$ \\
H-327 & 1780 & $14.8 / 6.7$ & $25.5 / 14.6$ \\
ETP-10 & 1750 & 10.8 & 58.8 \\
IG-11 & 1760 & $9.4 / 10.0$ & $34.7 / 32.8$ \\
IG-15 & 1894 & $11.8 /-$ & $49.0 /-$ \\
IG-43 & 1842 & $10.8 /-$ & $53.9 /-$ \\
IG-56 & 1730 & $10.3 /-$ & $43.1 /-$ \\
ISEM-3 & 1829 & $11.8 /-$ & $49.0 /-$ \\
ISO-88 & 1915 & $12.8 /-$ & $93.1 /-$ \\
SIC-6 & 1848 & $11.8 /-$ & $49.0 /-$ \\
\hline
\end{tabular}

C/C: (axial direction of fiber)/(perpendicular to fiber axis) GRAPHITE: (parallel to basal plane)/(perpendicular to basal plane)

究炉, HTTR)の炉心構造物に使用予定である。IG-15は IG-11 と同ビコークスを用い, 2 回含浸処理を行った高密 度材, IG-43はIG-11より微粒 $(\sim 10 \mu \mathrm{m})$ のコークスを用 いた高強度材である。IG-56は，IG-11 と同等であるが大 型ブロック用高強度材，ISEM-3はコークス( 10 10m の粒 径)のみを用いたバインダーなしの高強度放電加工用材 料, SIC-6 は半導体用高強度黒鉛である。また, HCB-

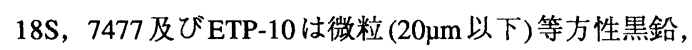
IM-2 はギルソナイトコークス系粗粒 $(\sim 1 \mathrm{~mm})$ 等方性黒 鉛, H-327は粗粒 ( 1mm) 異方性黑鉛である。この中で CC-312, CX-2002U, HCB-18S, ETP-10, 及びIG-11の超 高純度処理材であるIG-110Uは，実際にJT-60で使用さ れた炭素材料である。また, JT-60U(U:upgrade)では, JT-60で使用された炭素材料のうち HCB-18S と IG-110U 以外のものと IG-430U黑鉛(東洋炭素(株)製)及び 3 種類の $\mathrm{C} / \mathrm{C}$ コンポジット，すなわち MFC-1 (三菱化成(株)製), PCC-2(日立化成(株)製)，3D-C/C-S(敷島紡績(株)製)が 使用された。

超微小かたさの測定は島津製作所製ダイナミック超微 小硬度計(DUH-50)を用いて, 稜度115度の三角錐ダイア モンド圧子により，0.1gf，1gf，10gf，15gf，20gfにおい て実施し，荷重一押し込み深さ曲線を得た。実際のデー 夕取得は比較的滑らかな安定した曲線が得られた最小の 荷重すなわち $10 \mathrm{gf}$ と $15 \mathrm{gf}$ で行った。荷重負荷速度は $0.26 \mathrm{gf} / \mathrm{s}$ で 1 秒間負荷した。かたさ測定用試験片として

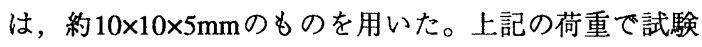
すると圧痕の最大深さは取得データから明らかなよう 

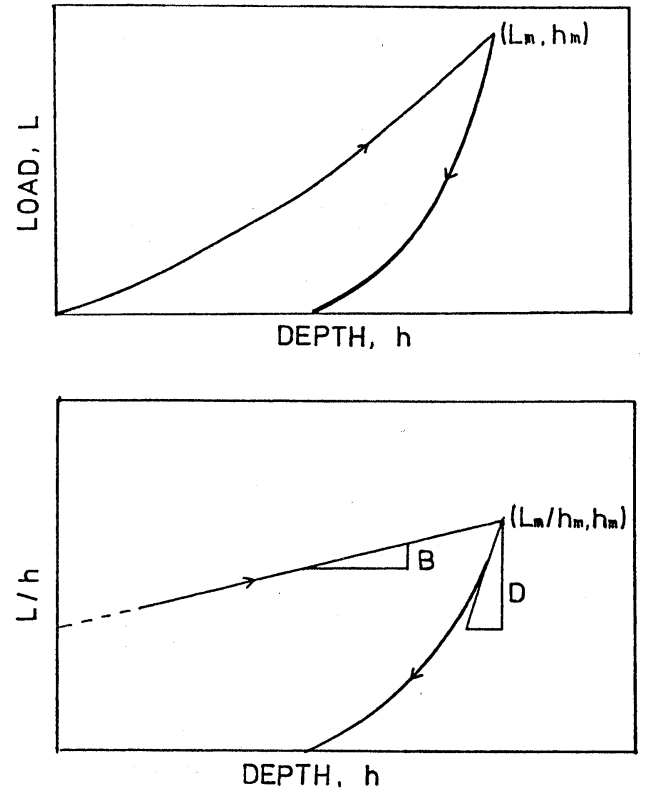

Fig.1 Schematic of Load(L)-depth(h) and L/h-h relations.

に，数 $\mu \mathrm{m}$ であるため，C/Cコンポジットで繊維の断面ま たは側面を試験した場合，圧子は瀻維のみでなくマト リックスにまでまたがることになった。

炭素材料では，弾性回復が大きいため，金属材料の場 合のような明瞭な圧痕は見られず，圧痕からかたさ值を 評価することはできなかった。

ヤング率測定用試験片は $5 \times 5 \times 50 \mathrm{~mm}$ のものであり，三 菱電機(株)製超音波深傷機(FD-1800)を用いて，5MHzの 振動子によって縦波の伝播速度(v)を測定した。ヤング 率 $(E)$ は，見かけ密度 $(\rho)$ を用いて，

$$
E=\rho v^{2}
$$

から計算した。

4 点曲げ試験は, ヤング率測定用試験片を用いて $0.1 \mathrm{~mm} / \mathrm{min}$ の速度で行った。 4 点曲げ試験における内ス パン長さは $18 \mathrm{~mm}$, 外スパンの長さは $39 \mathrm{~mm}$ であった。

C/Cコンポジットの各組織の強度評価は, 微細組織が 最もよく識別できた 3D-C/C 材を用いて行うことにし た。この材料を除く他の材料で強度評価の手法を検討 し，そこで得られた手法を用いて，3D-C/C材の各組織の 強度評価を試みた。

3D-C/Cコンポジット用繊維は，コンポジットと同じ条 件で熱処理し，1本づつ引張り試験を行い, 荷重一変位 曲線からヤング率と引張り強度を求めた。

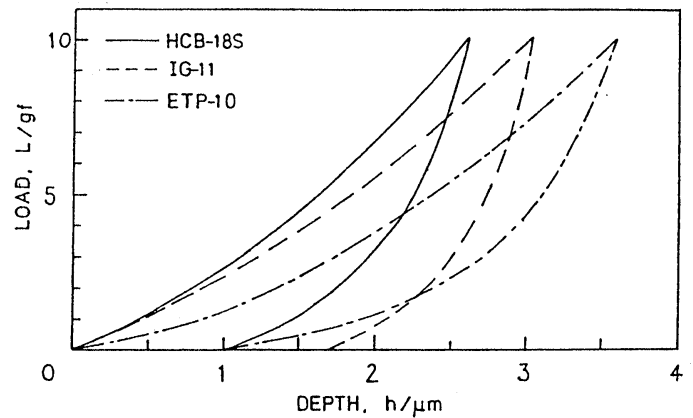

Fig.2 L-h curves for nuclear graphites.

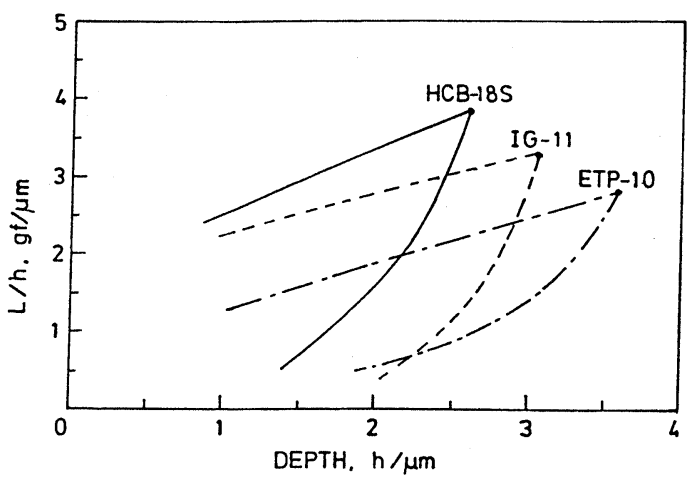

Fig.3 L/h-h curves for nuclear graphites.

\section{3. 実験結果と考察}

\section{1 負荷 · 除荷曲線}

ダイナミック超微小硬度計を用いれば，押し込み荷重 (L)と押し込み深さ (h)を連続的に計測できるので，Fig.1 の上図のような曲線が得られる。この曲線を同図の下図 のように, 縦軸 L/h は,

$$
\mathrm{L} / \mathrm{h}=\mathrm{A}+\mathrm{Bh}
$$

となり，除荷過程においては，

$$
\mathrm{L} / \mathrm{h}=\mathrm{D}\left(\mathrm{h}-\mathrm{h}_{\mathrm{m}}\right)+\mathrm{L}_{\mathrm{m}} / \mathrm{h}_{\mathrm{m}}
$$

によって表されると仮定した。

炭素材料の場合，負荷曲線はほほ直線となるので，その 勾配を Bとした。また，除荷曲線は必ずしも明確な直線 にならなかったので，最大荷重点における接線の勾配を Dとするか，または，L-h曲線の最大荷重点における接 線の勾配と(3)式を用いてDを求めた。

\section{2 力学パラメータ Bと D}

原子炉用黒鉛材料, HCB-18S, IG-11, ETP-10につい 


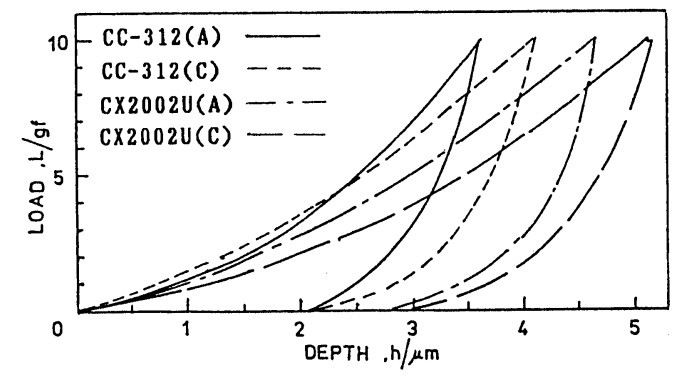

Fig.4 L-h curves for C/C composite.

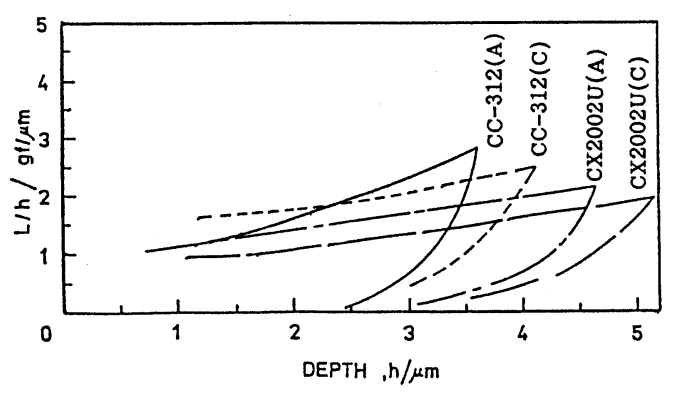

Fig.5 L/h-h curves for $\mathrm{C} / \mathrm{C}$ composite.

て，L-hの関係をFig.2に，(2)式と(3)式に対応する図を Fig.3に示す。これらは，Fig.1の典型的な例である。Fig.3 において, 負荷曲線の(2)式は描かれたすべての範囲の hの值についてよく成り立っていることが分かる。

次に, C/C コンポジットの CC-312(A\&C), CX-2002U (A\&C)のバルク(の形)でのL-h曲線及び L/h-h曲線の例を

Fig.4とFig.5に示す。ここで，Aは織維の軸方向に平行 な方向，Cは垂直な方向を表している。これらの図を用 いてパラメータ B と Dの值を求めた。パラメータ B と D の值を求めるにあたって使用した荷重はL-h線図の最大 荷重であり，ここで用いたすべての材料について Fig.6 の上部に示されている。1個の試験片について，その採 取方向を含めて約 10 個のデー夕を取得し，それらの平均 值と標準偏差を求めた。B,Dの両者には大きなばらつき が見られたが，そのばらつきはBよりDの方が幾分小さ かった。

\section{$3.3 \mathrm{~B}$ 值と曲げ強さとの関係}

金属材料では，力学パラメータBとDはそれぞれ引張 強度とヤング率に比例することが知られている1)。炭素 材料についてBとDの值をそれぞれの曲け強さ $\left(\sigma_{\mathrm{B}}\right)$, ヤ ング率(E)と対応させてグラフにしたのがFig.6と Fig.7で ある。ここで，曲げ強さとヤング率はそれぞれの材料に ついて得られた平均值をプロットし，BとDの值は標準

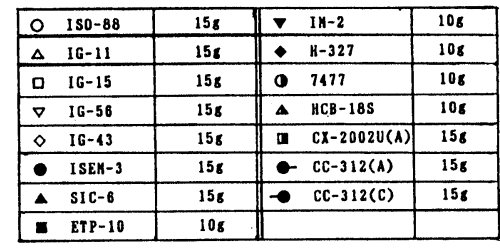

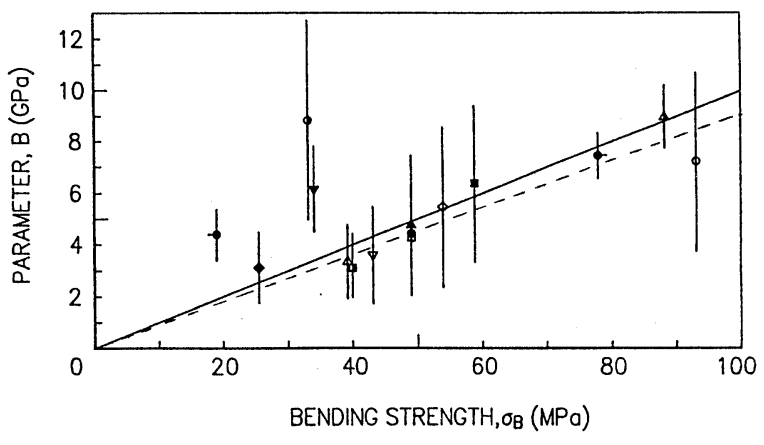

Fig.6 Correlation of parameter $B$ with bending strength for carbon materials.

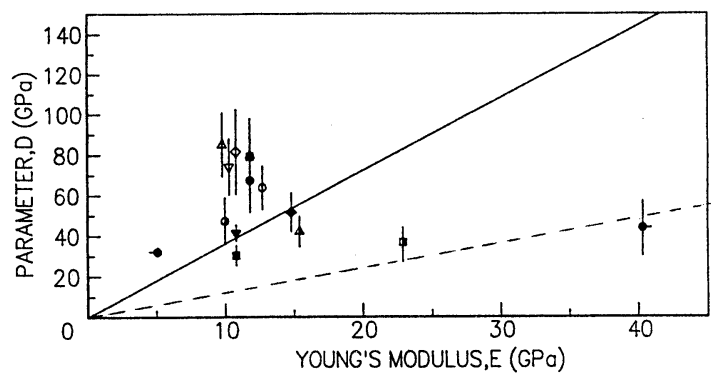

Fig.7 Correlation of parameter D with Young's modulus for carbon materials.

偏差でばらつきの範囲を示してある。Fig.6において， 実線は原点を通る平均值デー夕の近似直線，点線は金属 材料に対する関係を示している。Fig.6の場合，大部分 のデー夕はばらつきが大きく3銘柄については直線から も大きくはずれているが, 他の銘柄については，平均值 はほほ直線の近くにあると言える。B值のばらつきが大 きいのは，かたさ試験が10 $\mu \mathrm{m}$ オーダーの小さい領域を 対象にしているためと思われる。実線と点線はそれぞれ 次式で表される。

$$
\begin{array}{ll}
\sigma_{\mathrm{B}}=10 \mathrm{~B} & \text { (炭素) } \\
\sigma_{\mathrm{B}}=11.2 \mathrm{~B} & \text { (金属) }
\end{array}
$$

両者の差の一つは，曲げ試験の方がかたさ試験よりも大 
きな気孔の影響を強く受ける可能性があるため気孔のな い金属の場合より相対的に一定のB值に対して小さな曲 け強さを与えているものと考えられる。また，直線から ずれている場合について，その理由は明確ではないが， 考えられる可能性は以下のとおりである。7477黑鉛の粒 径は約 $70 \mu \mathrm{m}^{4)}$, 最多気孔径は数 $\mu \mathrm{m}^{5)}$, ISO-88黑鉛の粒径 は約 $10 \mu \mathrm{m}$ であり，さらに最多気孔径は $0.5 \mu \mathrm{m}$ 程度であ る。これらの材料においては，B值のばらつきが大きく なっているのは, 前述のように微小かたさ試験は微小領 域を対象にしており，押し込み深さが材料中に含まれる 気孔の大きさと同程度(数 $\mu \mathrm{m})$ であり，さらにコークス粒 子の異方性の影響を大きく受ける可能性のあることなど がその大きな原因ではないかと思われる。また，7477黑 鉛とIM-2黑鉛の場合，気孔が曲げ強度に影響を与えてい る可能性が考えられる。それに対して，パラメー夕Bを 求める基礎になっているかたさ試験は圧痕の大きさ(数 $\mu \mathrm{m})$ 以上のサイズをもつ気孔の影響はほとんど受けてい ないと考えられる。これが, 同じ曲げ強さに対してBの 值が大きくなっている主な理由であろう。CC-312(C)に ついても同様の理由が考えられる。

\section{$3.4 \mathrm{D}$ 值とヤング率との関係}

Dとヤング率Eとの関倸(Fig.7)において，実線は金属

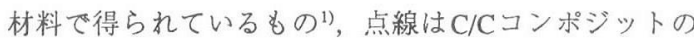
轼維軸方向の関倸を直線として表してみたものである。 これらはそれぞれ次式のようになる。

$$
\begin{aligned}
& \mathrm{E}=0.277 \mathrm{D} \quad(\text { 金属 }) \\
& \mathrm{E}=0.826 \mathrm{D} \quad(\mathrm{C} / \mathrm{C} \text { コンポジット }(\mathrm{A}))
\end{aligned}
$$

パラメータDとヤング率Eとの関係はFig.7に示されてい るように，相関性はあるが，よくない。金属材料に対す る関係である実線に近い関係を示す炭素材料もあると言 える程度である。 C/C コンポジットの CC-312(A), CX-2002U(A)に対する相関性は別の直線上にあるように 見受けられる。これは, 織維軸方向のかたさ試験では, 圧子先端近傍でき裂を発生しやすく，D值を小さくして いることによるものと思われる。

次に，微粒の黑鉛 IG-11，IG-15，IG-56, ISEM3, ISO88 及び SIC-6 の場合, D-E 関係は実線の上側にあ り，金属の場合に比べて，一定のヤング率 $\mathrm{E} に$ 対してD 值が大きくなっている。この理由は明らかでないがばら つきが大きくなる可能性は次のように考えられる。バル クのヤング率Eの測定值には気孔及びコークス粒子の異 方性の平均的な影響が入っている。また，D值について は，かたさ試験における荷重が小さく，気孔を避けて試 験を行っているので，とくに，大きな気孔の影響はそれ ほど受けていないことと粒子の異方性の影響を大きく受

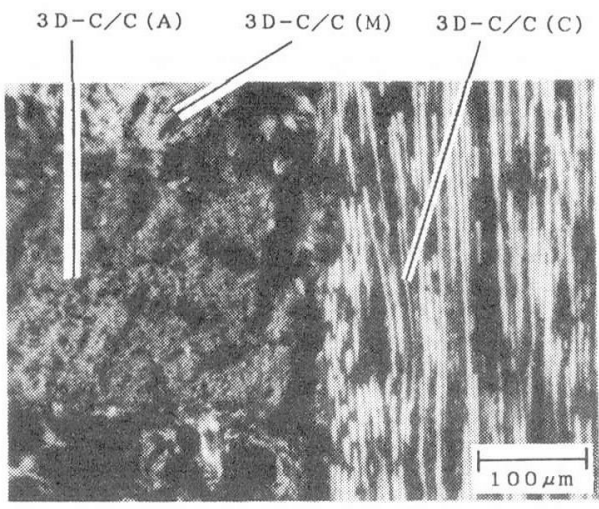

Photo 1 Microstructure of 3D-C/C composite.

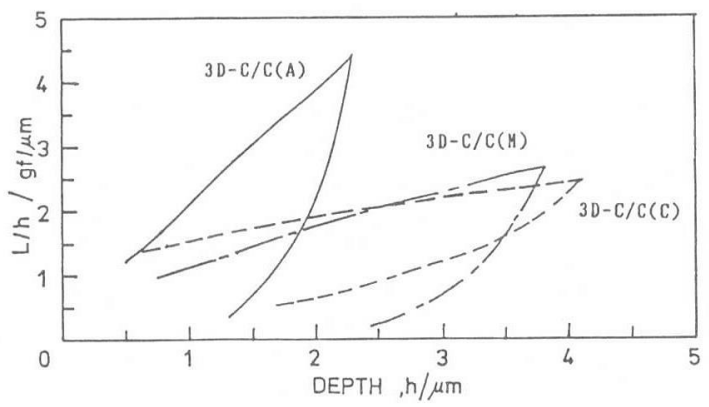

Fig.8 $\mathrm{L} / \mathrm{h}-\mathrm{h}$ relations for $3 \mathrm{D}-\mathrm{C} / \mathrm{C}$ composite.

けていると考えられる。そのことが，D值のばらつきが 大きい原因のひとつになっているものと思われる。

\section{$3.5 \mathrm{C} / \mathrm{C}$ コンポッジットの微細組織の特性評価}

$\mathrm{C} / \mathrm{C}$ コン゚ジットの繊維部分とマトリックス部分の強 度とヤング率をかたさ試験によって得られるB值とD值 から評価を試みることとする。前節までの結果から， B とDの值は強度やヤング率の值と必ずしもよい相関性が あるとは言えないが，ここでは，仮にそれらが金属材料 で得られているものと同じでるとし，さらに炭素瀻維 の軸方向については，Fig.7の点線の結果を用いて評価 することとした。試料としては，炭素瀻維とマトリック スを明瞭に識別できるC/Cコンポジットとして3D-C/Cを 取り上げて, 微細組織の強度とヤング率の評価を試み た。組織写真の例をPhoto 1 に示す。バルクの状態での それぞれの組織のL/h-h曲線をFig.8に示す。この図にお いて，3D-C/C (A)は C/C コンポジットの炭素繊維部分の 䋐維軸に平行な万问の結果であり，3D-C/C (C) は繊維の 軸方向に直角方向の側面に関する結果である。3D-C/C (M)はマトリックス部分の結果を示している。ここで, 瀻維軸に平行な方向の場合, 繊維の中心に負荷したとし 
Table 2 Bending strength and Young's modulus of each microsructure for 3D-C/C composite predicted from ultra-microhardness test.

\begin{tabular}{cccccc}
\hline Material & $\begin{array}{c}\mathrm{B} \\
\mathrm{GPa}\end{array}$ & $\begin{array}{c}\sigma_{\mathrm{B}} \\
\mathrm{MPa}\end{array}$ & $\begin{array}{c}\mathrm{D} \\
\mathrm{GPa}\end{array}$ & $\begin{array}{c}\mathrm{E}_{1}{ }^{*} \\
\mathrm{GPa}\end{array}$ & $\begin{array}{c}\mathrm{E}_{2}{ }^{*} \\
\mathrm{GPa}\end{array}$ \\
\hline 3D-C/C-A & 14.9 & 149 & 300 & 83.1 & 248 \\
3D-C/C-C & 3.74 & 37.4 & 28.9 & 8.00 & - \\
3D-C/C-M & 4.90 & 49.0 & 54.8 & 15.2 & - \\
\hline
\end{tabular}

$*: \mathrm{E}_{1}=0.277 \mathrm{D}, \mathrm{E}_{2}=0.826 \mathrm{D}$

Table 3 Results of bending test on 3D-C/C composite.

\begin{tabular}{cccc}
\hline Material & $\begin{array}{c}\text { Bend Strength } \\
\sigma_{\mathrm{B}} / \mathrm{MPa}\end{array}$ & $\begin{array}{c}\text { Tensile Modulus } \\
\mathrm{E} / \mathrm{GPa}\end{array}$ & $\begin{array}{c}\text { Comp. Modulus } \\
\mathrm{E} / \mathrm{GPa}\end{array}$ \\
\hline 3D-C/C & 102 & 96.6 & 102 \\
\hline
\end{tabular}

Table 4 Results of tensile test on the fiber given the same heat treatment as 3D-C/C composite.

\begin{tabular}{ccc}
\hline Material & $\begin{array}{c}\text { Tensile Strength } \\
\mathrm{MPa}\end{array}$ & $\begin{array}{c}\text { Young's Modulus } \\
\text { E/GPa }\end{array}$ \\
\hline 3D-C/C & $3070 \pm 600$ & $211 \pm 37$ \\
Fiber & $(30)$ & $(30)$ \\
\hline
\end{tabular}

ても，1gf〜2gf以上の荷重になると圧子の接触している 最大の大きさが繊維の直径をはみ出すほどの大きさに なってくるので，ここで実施した荷重 (10gf と 15gf)で は，必ず圧子はマトリックスにかかってくることにな る。繊維の径方向の場合も同様である。

Fig.8からBとDの值を求め，(4)，(6)及び(7)式を用い て， $\sigma_{\mathrm{B}}$ と $\mathrm{E}$ の值を計算すると Table 2 の結果が得られ る。次に, 3D-C/Cバルク材のA方向(フェルトを構成し ている繊維の軸方向のひとつ)の曲げ試験結果を Table 3 に示す。ここで, 右2列の值は, 曲げ試験におけるそれ ぞれ引張り側と圧樎側のヤング率である。Table 2 と Table 3を比較すると, バルク材の曲げ強さはほほ炭素 繊維の軸方向の強さによって決まっていると考えること ができる。また，ヤング率の值も繊維軸の方向の值の影 響を強く受けているが, 繊維の約半分の值となっている ことが分かる。マトリックスの特性は, 繊維の軸方向よ りはるかに小さく, 織維の径方向に近い值となってい る。

一方, 3D-C/Cコンポジットに用いられた緎維をC/C ンポジットと同に゙熱処理を加えた後, 引張り試験を行っ た結果を Table 4 に示す。カッコ内の数值は試験数であ る。繊維のヤング率はTable 2の 3D-C/C(A)の(7)式によ
る值である $\mathrm{E}_{1} よ り \mathrm{E}_{2}$ に近く, (7)式はC/Cコンポジット内 の繊維のヤング率の影響を強く受けた值となっているよ うに思われる。しかし, 強度の評価值は曲げ強さと引張 り強さの違いはあるとしても著しく小さな值となった。 かたさ試験の場合, 最大荷重付近では圧子がマトリック スにかかっているので, マトリックスの影響を強く受け て強度を小さく評価してしまうことが考えられる。

\section{4. 結論}

3 種類のC/Cコンポジット及び 12 種類の原子炉用黒鉛 等の超微小かたさ試験の結果をバルク材のヤング率測 定, 曲げ試験結果と比較検討することにより, 次の結論 が得られた。

(1)超微小かたさ試験における負荷曲線から得られるパラ メー夕Bは大きなばらつきを示すが, その平均值は $\mathrm{C} / \mathrm{C}$ コンポジットを含めて多くの炭素材料について, 曲げ強 さにほほ比例する。しかし，一部の炭素材料でこの直線 関係からずれるものがあった。そのため,ここで行った 試験条件では, かたさ試験による炭素材料の強度評価は 十分な精度で行えず，一般的には難しい。

(2)除荷曲線から得られるパラメータDとヤング率 Eとの 関係は, 多くの炭素材料について明瞭な直線関係にはな らなかった。しかし，C/Cコンポジットの繊維軸方向の D值については，2種類の材料に関してヤング率との相 関性が認められた。

(3)大部分の炭素材料について, 上で得られた Bの平均值

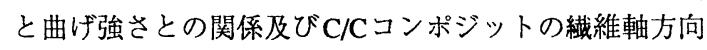
のDとヤング率との関係をそれぞれ直線で近似できると 仮定して，3D-C/Cコンポジットの各微細組織の負荷・ 除荷曲線から, 曲け強さとヤング率の評価を試みたとこ ろ,バルク材の曲げ強さとヤング率はそれぞれ炭素繊維 の軸方向の值の影響を強く受けていることを示唆してい た。

(4)C/Cコンポジット中の纎維の軸方向のヤング率はここ で行ったかたさ試験でおよその評価はできる可能性があ るが, 繊維の強度評価を十分な精度で行うにはもっと小 さな荷重による検討が必要である。マトリックスの強度 評価は逆に, 今後さらに大きな荷重による検討が必要で あると思われる。

謝 辞

本研究を実施するに当たり材料及び試験片を提供して 頂いた日本原子力研究所那珂研究所安東俊郎副主任研究 員に感謝の意を表する。実験の一部は, 卒業研究の一環 として多田満宏・原 正永・福田悦夫の各氏が行った。 ここに, 感謝の意を表す。3D-C/Cコンポジットの組織 
写真の撮影は東京工業大学安田策一教授のお世話になっ た。また, デー夕の解析法について東京大学鈴木敬愛教 授に種々ご教示頂いた。ここに感謝の意を表する。

\section{文献}

1) 稲村元則, 鈴木敬愛, 生産研究 42 (1990) 257-260.

2) T. Oku, S. Ota, M. Eto, Extended Abstracts, 20th
Biennial Conf. on Carbon, (1991) p.608.

3) 奥 達雄, 太田進哉, 衛藤基邦, 材料力学講演会講 演論文集, Vol.A, p.273(1991).

4) H. Kakui, T. Oku, J. Nucl. Mater. 137 (1986) 124129.

5）長谷川正義・三島良績監修，原子炉材料ハンドブッ ク, (1977) 367 , 日刊工業新聞社.

\section{日本学術振興会炭素材料第 117 委員会第 222 回委員会}

1. 日 時: 平成4年12月19日，20日

2. 場所: 主婦会館

3. 提出資料:

117-222-A-1 メソフェーズピッチを用いた金属超微粒 子分散炭素の調製

(九工試)児玉昌也, 中溝 実 (東京理科大)江角 邦男, 本田英昌

117-222-A-2 黒鉛層間での金属超微粒子の生成挙動 (大工試)塩山 洋, 岩下哲雄 辰已国昭, 澤田吉裕 (大阪電通大) 榊原裕之

117-222-B-1 歪抵抗効果による炭素綫維のキャラクタ リゼーションーゲージ率と構造一 (信州大) 遠藤守信, 北島保宏, 串橋卓馬

117-222-B-2 POLYMERIZATION of the ORGANIC LAYER in the SYSTEM $\mathrm{C}_{2} \mathrm{H}_{4}-\mathrm{CsC}_{24}$ (東京大工)H.PILLIERE, Y.TAKAHASHI T.YONEOKA, T.OTOSAKA (東京高専) N.AKUZAWA

117-222-C-1 材料設計の立場から見た C/C複合材料の 酸化挙動と繊維およびマトリックスの酸 化挙動との関係
(金材研)宮崎昭光, 冨塚 功 中沢静夫, 小泉 裕

117-222-C-2 微粒等方性黒鉛の微紐構造と特性に及ほ す圧縮予応力の影響

(茨城大工)奥 達雄, 太田進哉 (資環研)白石 稔 (原研東海)衛藤基邦 (日立日立研)後藤純孝

117-222-C-3 高炭素化収率のピッチをマトリックス前 駆体とした炭素繊維/炭素複合材料のマト リックス組織制御

(東工大工)木村修七, 堀田あいら 大沢栄也，安田公一，松尾陽太郎

特別講演 Stability of Graphite Intercalation Compounds

(CNRS) R.Setton

なお，20日午後2時より「特別シンポジウム」として 次の3件の講演と懇親会が盛会裡に行われた。

1) 学術振興会第 117 委員会の歴史(稲垣道夫氏)

2) 有機化合物における黒鉛骨格の設計 (大谷杉郎氏)

3) 炭素の電子物性研究 50 年の歴史(都竹卓郎氏) 